\title{
Situación Jurídica de la Compañía de Jesús en el Perú.
}

\section{ADVERTENCIA}

El trabajo que chora se publica fué escrito hace algunos años y lo morivó el hecho de haber oído decir a personas, por otra parte amigas de los Jesuítas y bien intencionadas, que no era legal su existencia en el Perú. No fióndome de mi propio parecer, dí a leer mi trabajo a lun amigo, el $\overline{D r}$. Carlos Arana Santamaría, bien conocido en Lima por su tacto y discreción y reputado como uno de los mejores abogados del foro peruano. El aprobó plenamente mi escrito si bien coneideró más prudente no darlo a la publicidad por entonces.

Para asequrame todavía mús, envié mi manuscrito a dos autoridades en la materia, el Dr. Félix Navarro Irvine $y$ el Dr. José Lsón Barandiarán. Sus amables y bien fundadas respuestas las hallará el lector al comienzo de este estudio. Respaldado por personas tan competentes lo doy a la estampa con el único fin de orientar en la materia a los que Lodavía conservaia los prejuicios de otra época. 
Lima, 2 de setiembre de 1947.

Reverendo Padre Rubén Vargas Ugarte,

Ciudad.

Distinguido Padre:

He leído con gran interés su trabajo sobre la situación jurídica de la Compañía de Jesús en el Perú y gustoso doy mi opinión sobre el tema.

La ley de noviembre de 1855 que prohibió el restablecimiento de la Compañía de Jesús en el Perú, desconoció principios sustanciales de nuestra organización política, enunciados en la Constitución entonces vigente -el Estatuto Provisorio de 1855- y concretamente violó el art. 21 de éste que reconocía como garantía nacional la inviolabilidad de los establecimientos de piedad $\mathrm{y}$ de beneficencia. Al disponerse en todas las Constituciones políticas del Perú, desde el Estatuto Provisonal de 1821, que la Nación profesa la Religión Católica, Apostólica y Romana, se reconocía que ella es uno de los elementos básicos de la nacionalidad $Y$ se violó este principio cuando en 1855 se negó a la Compañía de Jesús el trato a que tenía derecho conforme al régimen interno de la Iglesia Católica. Aunque, como usted muy bien lo destaca, no ha existido Concordato entre la Santa Sede y nuestro país, en una nación católica basta el reconocimiento que de tal carácter hace la Constitución, para que funcionen todos los derechos y prerrogativas de la Iglesia. Teniendo todos los institutos religiosos la misma legitimidad de origen. se violó la Constitución al hacer una excepción con dicha Compañía.

Empero no cabe duda que muy pronto, al promulgarse el 19 de octubre de 1856 la nueva Constitución, la ley de noviembre de 1855 quedó sin efecto, pues el art. 10 dispuso "es nula y sin efecto cualquiera-ley en cuanto se oponga a la Constitución". Y esta Constitución justamente, más que ninguna otra posterior, reconoció la autoridad de los cánones sobre las personas eclesiásticas (ari. $6^{\circ}$ in-fine), garantizó el funcionamiento de los establecimientos de enseñanza, piedad y beneficencia (art. 23), reconoció el derecho de asociación en cuanto no se alterara el orden público o privado (art. 28) y prohibió que se dictaran leyes que desconocieran la igualdad de las personas en todos sus derechos y garantias (art. 31).

Abrogada así la ley de 1855, ninguna importancia tienen los amagos esporkdicos que pretendieron revivirla entre los años 1874 y 1910 y que usted tan documentadamente cita. Siempre a ellos se opuso, con más o menos vigor, la tesis de la incompatibilidad de su existencia con los principios constitucionales ya anotados $y$ al respecto nada tengo que agregar a las precisas opiniones de los juristas Villarán, Lavalle, Cavero que usted saca a ia luz.

La ley de 1855 ha quedado pues sepultada no por acción del olvido o del desuso, sino por expreso mandato constitucional. Avanzada la cultura jurídica del país a nadie se le ha ocurrido en las últimas décadas que sea ilegal el establecimiento de la Compañía de Jesús ni que haya constituído 
una extralimitación autorizar el funcionamiento de sus centros docentes y de piedad. Las demostraciones son obvias y tenemos que concluir que esta cuestión ha pasado enteramente a la historia.

Hoy en nuestro Derecho Positivo lejos de existir la más leve reminiscencia de esa inconsulta política, las comunidades religiosas gozan por sí mismas de personería jurídica sin que se exceptúe a ninguna de ellas. La única formalidad que se les exige es la de su inscripción civil, que por cierto no puede serles negada. Esto resulta claramente del texto del art. i057 del Código Civil vigente. Ignoro si la Compañía de Jesús ha llenado dicha formalidad, pero sin duda que puede en cualquier momento hacerlo. Así tendrá una plena confirmación de la tesis que usted ha desarrollada con tanto acierto y que modestamente abraza quien queda como su affmo y's. s.

\section{Félix Navarro Irvine}

Lima, 23 de mayo de 1953.

Reverendo Padre Rubén Vargas Ugarte,

Ciudad.

\section{Distinguido Padre:}

Con el mayor agrado le expreso mi parecer acerca de la situación jurídica en el Perú de la Compañía de Jesús.

Desde todo punto de vista dicha Compañía es como persona moral, una que goza de los derechos inherentes a su carácter de tal, y no hay ni podía haber pretexto legal alguno para negarle su capacidad de existencia y de ejercicio en cuanto a sus lícitas actividades.

La ley de noviembre de 1855, que prohibiera el restablecimiento de dicha Compañía no puede considerarse con vigencia, ni eficacia tampoco alguna, para desconocer tal existencia y capacidad del mencionado ente sccial.

Es un principio jurídico que comprende el reconocimiento de un derecho humano, el de poderse constituir asociaciones para fines que condigan con el orden público y las buenas costumbres, lo que indiscutiblemente ocurre en el presente caso considerado. Cualquiera decisión que descono. ciese este derecho repugnaría a una de las garantias fundamentales que siempre se ha reconocido en el Perú, como en todo régimen jurídico. La Constitución política de 1856 y las posteriores han consagrado tal derecho de asociación.

La ley de noviembre de 1855 , antes referida, no puede tener aplicc- 
ción, pues se oponía ya, al ser dictada, a preceptos incursables del régimen constitucional normativo del Estado del Perú. Cabe, en efecto, referirse a dispositivos de la Constitución de 1839. Aunque en 1855 se había dictado el Reglamento Provisorio, ello no significaba la derogatoria in complexu de la Constitución de 1839, pues no se consigna en aquél la respectiva disposición derogatoria; de suerte que sólo no podía aplicarse dicha Constitución de 1839 en lo que era implicante con el mencionado Reglamento Provisorio.

Ahora bien, la Carta Política de 1839 estableció que era libre todo género de trabajo, industria o comercio, salvo en cuanto estuviere en pugna con el orden público (art. 169); que se garantizaba la existencia de los establecimientos de piedad y beneficencia (art. 174); que nadie estaba impedido hacer lo que la ley no prohibe (art. 176). Parece ocioso comprobar que la Compañía de Jesús quedaba amparada por preceptos citados, con tanta mayor razón cuanto que el art. $3^{\circ}$ indicaba que la Nación profesa la religión católica.

De todos modos la ley de 1855, así no se hubiere chocado con principics normativos fundamentales que la nulificaban automáticamente, ella quedó sin vigencia al promulgarse la Constitución de 1856, que en su art. 10 dispuso que era nulo y sin efecto cualquiera ley que se opusiera $\alpha$ la Constitución. Y la ley de 1855 se oponía irremisiblemente a terminantes artículos de dicha Constitución de 1856, como el 23, que garantizaba el funcionamiento de establecimientos de enseñanza, piedad y beneficencia; el 24, que reconocía el derecho para ejercer libremente la enseñanza y dirigir establecimientos para tal finalidad; el 28, que consagraba el derecho de asociarse; el 31, que indicaba que la ley protege y obliga igualmente a todos en sus personas y bienes. ¿Cómo, pues podría concebirse que funcionase una prohibición tan odiosa, como la ley de 1855, cuando ella se opuso ya al dictarse, a normas constitucionales $y$, de todos modos, resulta invalidada por las que después se expidieron?

No cabe ningún género de duda sobre que la Compañía de Jesús tiene el amparo jurídico que le corresponde como a toda persona colectiva.

Me suscribo su amigo y obsecuente servidor,

José León Barandiarán 


\section{Establecimiento de la Compañía de Jesús en el Perú}

Felipe II por carta de 3 de Marzo de 1566 pidió al General de la Compañía, San Francisco de Borja, 24 sujetos para el Perú, encargándole fuesen tales cuales convenían para esas partes. No pudo el Santo Duque, antiguo valido y confidente del Emperador, satisfacer por entero los deseos del Monarca, pero mandó alistar una expedición de 8 sujetos, escogidos de entre las 4 Provinciass españolas y puso al frente al P. Jerónimo Ruiz del Portillo, perteneciente a la de Castilla. Embarcáronse en Sanlúcar el 2 de Noviembre de 1567 y con próspero viaje arribaron a Panamá en Enero de 1568, reanudando poco después la navegación por el Pacífico. Dieron fondo en el Callao el 28 de Marzo de 1568 y el $1^{\circ}$ de Abril hacían su entrada en Lima, con grande contento del Arzobispo, D. Fray Jerónimo de Loaiza, del Licenciado Castro, Gobemador entonces por Su Magestad y del vecindario.

El Rey había dirigido a su representante la siguiente Real Cédula en donde consta ser su voluntad que la Compañía se estableciese en el Perú y el fin para el cual eran enviados sus hijos. Dice así textualmente: "El Rey. Licenciado Castro, del nuestro Consejo de las Indias y nuestro Presidente de la Real Audiencia que reside en la ciudad de los Reyes. Saved que Nos por la devoción que tenemos a los de la Compañía de Jesús por su buena vida y recogimiento avemos acordado enviar algunos de ella a las nuestras Indias porque esperamos que con su doctrina y buen exemplo harán mucho fruto en la instrucción y conversión de los indios naturales dellas y así enviamos de presente $\alpha$ es a tierra catorce dellos para que empiecen a fundar su Orden en ella y porque mi voluntad es que se les dé para ello el favor necesario, vos mando que pues esta obra es para el servicio de Dios y exaltación de la fé católica, luego que los de la dicha Compañía llegaren $\alpha$ esta tierra les recibáis bien $y$ con amor y les déis y hagáis todo el fabor y ayuda que viéredes convenir para la fundación de la dicha Orden en esa tierra, para que mediante ella hagan el fruto que esperamos y para que lo acierten mejor a hacer, vos les advertiréis de lo que pareciere que conviené como persona que entiende las cosas de la tierra y señalarles héis sitio donde puedan hacer sus casas e Iglesias, haciendo con ellos en esto lo que con los demás religiosos de las otras órdenes que en ello seré muy servido. Fcha. en Madrid 11 de Junio de 1567 años. Yo el Rey. Por mandado de Su Magestad. Francisco de Eraso".

En virtud de esta orden el Licenciado se apiesuró a buscar casa don. de pudiesen establecerse y dispuso que de la Real Hacienda se diesen 2200 pesos para comprarla, dando comisión al Oidor Cuenca para todo lo concerniente a la cómoda instalación de los religiosos. Escogióse la cuadra fronteriza a las casas del Capitón Diego de Agüero, desde la esquina, pro- 
piedad de Gaspar Báez hasta las que eran propiedad de Diego de Porras Sagredo, por una parte y Alonso Díaz Merino, por otra. Montó el total de los solares que se compraron 12670 pesos que se pagaron con lo erogado por el Licenciado Castro a nombre del Rey, lo que dió el Arzobispo y las limosnas particulares. Entregada que fué esta suma a los propietarios, el Corregidor de Lima, Manuel Alonso de Anaya, ordenó se cumpliese lo previsto por el Licenciado $\mathrm{y}$ puso en posesión de todo el terreno escogido al P. Jerónimo huiz del Portillo. De este modo y por orden expresa del Rey comenzó la Compañía en el Perú a ejercer los ministerios propios de su Instituto y a gozar de todos los derechos y preeminencias que le habían otorgado los Sumos Pontífices y le reconocía el Estado español.

II

\section{Expulsión de la Compañía por Carlos III}

Tal estado de cosas perduró hasta el año 1767, en que por Real Decreto de 27 de Febrèro dispuso Carlos III el extrañamiento de todos los individuos jesuítas de sus dominios de España y Ultramar, guardando en su real pecho los motivos que tenía para hacerlo y que hoy la historia veroz no desconoce. El decreto no sólo envolvía la expulsión de los hijos de la Compañía sino la abolición de la Orden dentro del territorio sujeto al Rey Católico, de modo que ella vino prócticamente a quedar extinguida en España y América.

La brutal orden fué trasmitida con toda la celeridad que la época permitía y al Virrey D. Manuel de Amat, le fué enviada por dos conductos, por Panamá y Buenos Aires. De estos dos correos el primero en llegar fué el de Buenos Aires y la intimación del decreto se realizó en Lima el 9 de Setiembre, al amanecer. Sucesivamente se fué comunicando la orden a las. diversas casas de la Provincia, aún a las más distantes, incluyendo las Misiones de Mojos y a medida que fueron llegando los religiosos a los puertos de embarque, o sea al Calloo y Arica, se les remitió $\alpha$ España, a unos por la vía del Cabo de Hornos y a otros! por la de Panamá. Un año después de estos sucesos todos los domicilios de la Compañía en el Perú, Y sus propiedades rústicas y urbanas habían pasado a manos de la Hacienda Real o mejor dicho a una Junta especial, encargada de su administración, que se llamó de Temporalidades, la cual subsistió hasta los primeros días de la emancipación.

Esta inaudita y violenta medida que arrancó de su suelo patrio a más de 3000 jesuítas americanos, entre los cuales se contaban más de 400 del Perú, subsistió como Ley del Estado hasta el año 1815, en que fué derogada por el sucesor de Carlos III en el trono de España, Fernando VII.

\section{III}

Restablecimiento legal de Ia Compañía de Jesús en España y América

Los pueblos de América sintieron desde el primer instante la falta que en ellos hacían los Jesuítas y en cuanto se les ofreció oportunidad de ma- 
nifetsar su pensamiento, demandaron de un modo público y solemne el que fueran restablecidos de hecho y de derecho en estas comarcas. Tal ocurrió en las llamadas Cortes de Cádiz, convocadas por el Consejo de Regencia, durante la cautividad de Fernando VII, en el año 1811. En la sesión del 9 de Abril, todos los diputados americanos, con excepción del quiteño José Mejía Lequerica, pidieron la aprobación de la siguiente propuesta: "Reputándose de la mayor importancia para el cultivo de las ciencias y para el progreso de las Misiones que introducen y propagan la fé entre los indios infieles la restitución de los jesuítas, se concede para los Reinos de América".

Todos los representantes del Perú, interpretando los deseos de los habitantes del Virreinato, que les eran bien conocidos, defendieron esta proposición, que no llegó a merecer la aprobación de la Asamblea, porque todavía pesaba demasiado sobre muchos de sus miembros la influencia regalista y jansenista que había dado origen al decreto de expulsión. Fernando VII, al ser restituido a su trono, acalló los prejuicios que por la sangre y por la educación había heredado de sus progenitores y comprendió que entonces más que nunca se hacía necesaria la ayuda de los jesuítas. En consecuencia, el 29 de Mayo de 1815, dió un decreto, en virtud del cual vino en mandar "que se restablezca la Religión de los Jesuítos, por ahora, en todas las ciudades y pueblos que los han pedido, sin embargo de lo dispuesto en la expresada Real Pragmática Sanción de 2 de Abril de 1767 y de cuantas leyes y Reales Ordenes se han expedido con posterioridad para su cumplimiento, que derogo, revoco y anulo en cuanto sea necesario para que tenga pronto y cabal cumplimiento el restablecimiento de los Co. legios. Hospicios, Casas Profesas y de Noviciado, Residencias y Misiones establecidas en las referidas ciudades y pueblos que los hayan pedido; pero sin perjuicio de extender el restablecimiento a todos los que hubo en mis dominios..."

Habiendo solicitado los diputados del Perú el restablecimiento de la Compañía se podía con fundamento creer restituida la Orden en todos sus aerechos en el territorio de este Virreynato, mas, para quitar toda duda el 3 de Mayo de 1816 ordenó el Rey se extendiesen los efectos de dicha Real Cédula a toda la Monarquía, sin restricciones y mandó que los Virreyes y Gobernadores obedeciesen a la Real Junta creada con el objeto de atender a la vuelta de los jesuítas y a la entrega que había de hacerse de sus domicilios. El tenor de este documento en la parte que nos interesa decía así: "Mando que el permiso que tengo concedido por mi Real Decreto de 29 de Mayo último, con derogación de la pragmática, leyes y Reales Cé. dulas que en él se citan, para el restablecimiento de la Compañía de Jesús en las ciudades y pueblos del Reino que me lo habían pedido en aquella época, sea extensivo, general y sin limitación a todos los demás de mis dominios, así de España como de las Indias e Islas adyacentes en que se hallaba establecida dicha Religión al tiempo de su extrañamiento. Autorizo con la licencia necesaria a los Superiores e individuos que son y fueren de la Compañía para que puedan volver a dedicarse en estos Reinos al ejercicio y práctica de la vida regular y funciones de su profesjón religiosa... A fin de que se verifique la restauración de la Compañía con la brevedad 
que deseo y conviene a la felicidad espiritual y temporal de mis Reinos, es mi soberana voluntad "que se la devuelvan y restituyan las Casas, Colegios, Iglesias, Hospicios, Residencias, bienęs y rentas que se la ocuparon al tiempo de la expulsión y se hallan existentes en la actualidad..."

Esta Real Cédula fué confirmada y ampliada por la de 11 de Junio de 1816 y trasmitida al Virrey del Perú, el cual la hizo imprimir en lima el 22 de Mayo de 1817, a fin de que pudiera circular por todas las provin. cias del Virreinato $y$ de un ejemplar de la misma hemos extractado los párrafos precedentes. A mayor abundamiento, D. Joaquín de la Pezuela que gobernaba entonces a nombre del Rey, hizo publicar en la Gaceta del Gobierno de 9 de Abril de 1816 el decreto de restablecimiento de 29 de Mayo de 1815, con lo cual y la promulgación del de 11 de Junio de 1816 se dió suficiente noticia de las reales disposiciones. Estas, por voluntad del Monarca y en conformidad con la próctica establecida quedaron incorporadas a las leyes de la Recopilación $y$ venían por consiguiente a ser ley del Esiado.

Por tanto, al sobrevenir la Independencia, la Compañía de Jesús como cualquier otra Orden religiosa estaba amparada por las leyes, reconocidas por el Estado, tenía personalidad jurídica y podía reclamar la propiedad de los bienes que le habían sido arrebatados $y$ que aún subsistían administrados por la Junta de Temporalidades.

\section{IV}

\section{La vuelta de los Jesútas al Perú}

Esta era la situación de derecho en 1824, año en que se consumó nuestra independencia. Por desdicha, la Compañía de Jesús no pudo distrutar de hecho de las garantías que le otorgaban las leyes, porque ninguno de sus miembros alcanzó a volver en esos días a nuestras playas. No obstante, conviene observar que el cambio de régimen político no introdujo ninguna mudanza sustancial en las precitadas disposiciones, pues tanto el Reglamento Provisional, dado por San Martín, el 12 de Febrero de 1821, como el Estatuto Provisorio de 8 de Octubre del mismo año y la Ley de 6 de Octubre de 1822, declararon vigentes todas las leyes emanadas del gobierno español q'ie no se oponían a la independencia de la nación o contradijesen a las promulgadas por el Gobierno independiente. En la prác. tica tal fué el procedimiento que se siguió en los tribunales de la República, de manera que nada obstaba para que la Compañia de Jesús volviera a establecerse en el Perú y continuara ejerciendo sus actividades entre nosctros. Vino a confirmar lo dicho la Constitución del año 1828, la cual en su art. 131 establecía que "Todas las leyes que no se opongan a esta Constitución quedan en su vigor y fuerza hasta la organización de los Códigos".

Como es sabido, estos no vinieron a publicarse sino hasta el año 1852, después de algunas telatativas y proyectos que no llegaron a obtener la aprobación del Congreso y en vano se hallará en ellos alguna disposición que derogue, limite o reduzca el derecho que poseía la Orden de Ignacio. Esta. sin embargo, tardaba en reaparecer en nuestro suelo. México, la Argentina. 
Chile, Colombia y el Ecuador habian celebrado con júbilo la reaparición de los jesuítas, pero nuestra patria, la primera en acogerlos en suelo americano y de donde la Orden se había extendido por todo el Continente, continuaba huérfana de ellos. Múltiples voces se habían elevado acá y allá, reclamándolos e instando porque volviesen, pero circunstancias diversas habían frustrado estos votos. En 1816, al saber que el Soberano accedía a que volviesen allí donde fueren pedidos por las poblaciones, los Cabildos de las más importantes ciudades del Perú elevaron sus preces para que se les enviasen algunos sujetos. Lima, el Cuzco, Cajamarca, Huancavelica, Trujillo y Lambayeque, entre otras, los reclamaron y expresciron el común sentir de los habitanies del Virreinaio. No disminuyó este anhelo, antes bien, en cuantas ocasiones se ofrecieron, como ocurrió a su llegada a Chile, donde tuvo ocasión de tratarlos el célebre D. Francisco Javier Luna Pizarro, se puso de manifiesto.

Sólo de una manera esporádica llegaron hasta nosotros algunos jesuítas y no nos dotendremes en dar sus nombres, pero sí es oportuno mencionar el arribo de un grupo de ellos, desterrados del Ecuador. En el año 1852 los PP. Luis Segura, Pablo Pujadas, Manuel Fernóndez, León Tornero, Francisco Javier Hernáez y los HH. Juan Garriga y Luis Sarasola fueron embarcados en Guayaquil por orden del Presidente Urbina a bordo de un bergantín francés, cuyo capitán debía conducirlos a Panamá. Este de acuerdo con los proscritos, varió de plan y los dejó en la playa de Tumbez, aun cuando dicha caleta no estaba entonces habilitada para recibir pasajeros. Nadie se opuso a su desembarco y los jesuítas hallaron modo de trasladarse al vecino puerio de Paita. A su arribo vino a saludarles la primera autoridad marítima $y$ con toda atención les manifestó que no se opondría a su permanencia en el lugar, pero que debía pedir instrucciones al Gobiemo. Hallábase al trente del poder el General Echenique, de tendencia conocida. mente conservadora y su respuesta fué que no se inquietase a los desterrados y se les dejase en libertad para ir donde quịsiesen. En vista de ello, los PP. Segura y Hernáez se encaminaron a Piura; a ellos, días más tarde, se les unió el H. Lizarzaburu, venido también del Ecuador, mientras los otros aquadaron el barco que había de conducirlos a Centro América.

Existía en la ciudad una capilla denominada del Carmen que en otro tiempo había sido residencia de los jesuítas de Quito y allí se establecieron los Padres, ejercitando sus ministerios en provecho de los prójimos con aplauso de todos los buenos, desde Febrero de 1852 hasta el siguiente año en que recibieron orden del P. Camilo de Blas de pasar a Guatemala.

Mas ya se acercaba el momento en que se verían cumplidos los deseos expresados por el célebre D. Mateo Aguilar en su Panegírico de S. Ignacio: una rama desgajada del órbol de la Compañía sería trasplantada a nuestro suelo y en él reverdecería para cubrirse de nuevo de trutos. Al dirigirse a Roma, con motivo de la celebración del Concilio Vaticano, el Obispo de Huánuco Mons. Manuel Teodoro del Valle, llevaba en su mente el plan de traer consigo algunos hijos de S. Ignacio que tomaran bajo su dirección su Seminario diecesano. Había comunicado su proyecto con el Presidente Balta $\mathrm{Y}$ su Ministro de Culto, D. Manuel Pardo y había obtenido de entreambos su aprobación. Ya en la ciudad santa, entrevistóse con el 
General de la Compañía, R. P. Pedro Beckx y obtuvo que éste le concediese algunos religiosos. Corría el año 1869 y, por lo pronto, fueron designados para venir al Perú cuatro sujetos, los PP. Jorge Sendoa, Mateo López, Ga. bino Astrain y el H. Saturnino Villalba. Entre tanto el General escribía al Visitador de la Misión del Ecuador, P. Agustín Delgado, a fin de que desde allí se enviasen otros tantos.

El primer grupo zarpó el 14 de Agosto de 1871 del puerto de Saint Nazaire y el 16 de Setiembre hacía su entrada en Lima, siendo acogidos con mucha caridad por los PP. de la Merced. No mucho después fijaron sil residencia en el convento supreso de $\mathbf{S}$. Pedro Nolasco. Unos días más tarde, el 25 de Setiembre, se les unía el segundo grupo, formado por los PP. Francisco Javier Hernáez, Antonio Garcés y el H. Patricio Salazar. Aunque su entrada la habian hecho calladamente $\mathrm{Y}$ cual si fuesen sacerdotes seculares, pronto cundió la noticia y un caballero que había sido su compañero de viaje les dió la bienvenida desde las columnas de "El Nacional". ¿A qué se debía este recato y las precauciones que hubo de tomar el Obispo de Huánuco, al traer a los jesuítas? ¿No se podía considerar legal su restablecimiento? ¿Habíase dado alguna ley en contrario? Vamos a verlo.

\section{La reacción antijesuítica}

E] triunfo de Castilla sobre Echenique trajo consigo el predominio del elemento liberal y no tan sólo del moderado sino aun del radical, encarnado en el chileno Francisco Bilbaa y los del grupo que sostenía el periódico titulado "El Porvenir". La Masonería, que existía entre nosotros desde los primeros años de la independencia, no permaneció tampoco ociosa y apoyó la campaña antireligiosa y anticlerical que se proponía obtener del Gobierno la tolerancia de cultos. En tan revuelto mar de pasiones se llegó hasta a atacar los dogmas de la iglesia y "El Comercio" de Lima prestó sus columnas para que desde ellas infiriera esta ofensa a nuestros sentimientos católicos el genio desequilibrado de un extranjero. La ofensa no pudo menos de llamar la atención de la justicia y el Fiscal de la Corte denunció el escrito, por lo cual fué Bilbao sometido a prisión $y$, por evitarse las molestias de un juicio, abandonó el país.

Como ya se deja entender, en el seno de la Convención, instalada el 14 de Julio de 1855, predominaba el elemento liberal y extremista. Los partidarios de Echenique, conservadores en su mayoría, fueron excluidos deliberadamente en la elección y los representantes de un pueblo de arraigadas creencias religiosas hicieron alarde de un liberalismo que en su mezquino concepto venía a ser un simple $y$ vulgar anticlericalismo. En medio de este estado de cosas no puede sorprender que la Convención diera el 23 de Noviembre de 1855 una ley proscribiendo a los Jesuítas, re. frendada luego por el Ejecutivo el 30 del mismo mes. (V. Documento No 1). Sólo la pasión política o la inconsciencia de los legisladores pudo arrastrarlos a dar una ley que estaba en contradicción con los principios del sistema liberal, fuera de no existir entonces jesuítas en el Perú ni probabi- 
lidad de que pudieran venir $\alpha$ instalarse en el país. Un pretexto pudieron alegar o sea la actividad que por entonces desplegaban los religiosos franciscanos descalzos, llegados no hacía mucho al Perú y cuya predicación venía cosechando copiosos trutos en el pueblo. Pero los Jesuítas por ningún lado aparecían.

Sin embargo, en la perturbada fantasía de algunos de los convencionales, como un señor Matute, que dejó triste huella de su paso por la Cónmara, muchos de los religiosos o sacerdotes que cumplían con los deberes de su profesión en el país eran jesuítas. Fué este diputado el autor de la moción contra estos religiosos y le secundaron no sólo sus amigos los radicales sino también muchos otros que no se avinieron a suscribir con ellos el proyecto de tolerancia de cultos. La derrota sufrida por los primeros en esta parte, los animó a desquitarse, ensañándose contra los jesuítas. Como muy bien lo advertía "El Católico", en su número de 24 de Noviembre de 1855, los partidarios de la tolerancia habían incurrido en palmaria contradicción al cerrar las puertas del país a un instituto que era admitido en las naciones más cultas de Europa. "A la par que se desea el progreso, a la par que se grita libertad y engrandecimiento, se autoriza la desmoralización y se obstruyen los canales por donde debiera correr el agua balsámica que morigera al hombre en la sociedad, con el desacordado proyecto de la no admisión de los jesuítas. Estaba reservado al Perú en el siglo XIX tan extraña aberración, inconsecuencia tan manifiesta".

Por fortuna no faltó una voz que defendiera a los Jesuítas y ésta fué la del diputado por Piura, D. Ignacio Escudero. Al discutirse el proyecto presentado por los liberales, según el cual debía renovarse por el Eecutivo el decreto de extrañamiento de los Jesuítas dado por Carlos III. Escudero expuso que era necesario decidirse o por la admisión de los Jesuítas o por su proscripción y que su Provincia deseaba vivamente que fuese restablecida la Orden en el Perú y lo había manifestado hacía tiempo en una representación que le fué enviada en su calidad de 'síndico de la Municipalidad, a fin de que la elevase al señor Obispo de Trujillo. Ahora, como representante de ella no hacía sino interpretar su voluntad. Después de señalar la contradicción en que incurren los llamados liberales, aceptando la entrada en el país de judíos o mahometanos y rechazando $\alpha$ unos sacerdotes católicos, dijo que el restablecimiento de la Compañía venía a ser una necesidad imperiosa para el país, tanto por el relajamiento que se observa en las costumbres como por la necesidad de levantar el nivel del clero. El temor que abrigan algunos de su intervención en la política es infundado y si se les combate por esta razón habría también que dirigir las armas contra el clero nacional que interviene en la política. (1) Su palabra no fué escuchada y prevaleció la pasión y la consigna dada por las logias sobre el buen sentido y los verdaderos anhelos del país.

(1) Exposición que hace el Diputado Ignacio Escudero ante la Nación y la Provincia do Piura de sus tareas Parlamentarias en lá Convención Nacional de 1855. Piura, 1858. Impreso por Miguel Vósquez. 229 p. n. 1 en bl. ₹ 4 s. n. de Indice $₹$ Fé de Erratas. v. p. 108. 


\section{Comienza la oposición}

Lua vuelta de la Compañía halló fuerte oposición en los liberales y mascnes. Los buenos se pondrían de su parte pero entonces y aún después se advertía en unos falta de decisión y en otros un mal velado temor de atraer sobre sí el odio de los enemigos. El pueblo, después de una ausencia más que secular, ya había olvidado a la Compañía y no podía ponerse de su lado si no es aisladamente. Los Padres habían pasado a Huánuco $Y$ habían tomado a su cargo las clases del Seminario, ejercitando los demás ministerios en la Iglesia de la Merced que el Obispo puso a su disposición. Acompañaron a éste en la visita de la provincia de Tarma y en esta ciudad y en las de Jauja y Cerro de Pasco dieron misiones fructuosísimas que dejaron recuerdo imborrable. Entre tanto los pocos que habían permanecido en Lima dividieron su actividad entre el confesionario y la predicación y la enseñanza en el Colegio Nacional Pardo y el dirigido por el excelente caballero católico D. Melchor García. El horizonte, aunque oscuro, no parecía presagiar una tempestad próxima, cuando he aquí que Don Gregorio Paz Soldán, empecinado regalista y acérrimo propugnador de la sujeción de la Iglesia al Estado, denunció como Fiscal de la Nación el 24 de Febrero do 1874, al Ministro de Cúlto la existencia, a su juicio ilegal, de los jesuítas en Huónuco. (V. Documento N 2).

El origen del aiaque lo hallamos en la vulgar $i$ mezquina rivalidad que suscitó en el capellán de la Merced de Huánuco la presencia de los jesuítas. Estos habían escogido aquella iglesia como campo de sus operaciones no por propia iniciativa sino por indicación del Obispo, pero, yendo tal vez más allá de lo que exigían las circunstancias, decidieron instalarse en unos aposentos vecinos al templo y aún comenzaron a construir algunas habitaciones sobre la sacristía y sus dependencias. Esto ciebió irritar al capellón nombrado por el Gobierno y al cual se le abonó en todo tiempo la renta señclada. Entendióze con el Prefecio y éste, por amistad con el capellán o poy odiosidad contra ios jestítos, pasó una nota al Obispo, pro testando de la intromisión de estos religiozos y, no contento con esto, dió aviso de lo ocurrido al Ministerio. Este no debió de der importancia al hecho, porque no intervino sino con motivo de la nota de Paz Soldán. Según el Fiscal la ley se hobía infringido de dos incneras: Primero, porque en la Recopilación de las Ieyes de Indias se prohibía expresamente la fundación de conventos sin la licencia respectiva del Patrono (o sea el Rey) juzgando. equivocadamente que en el Perú aún subsistía el derecho de Patronato y que éste lo habian heredado los Presidentes de la República. Segundo, que se había violado la ley de 23 de Noviembre de 1855 que prohibía expresamente el establecimiento de los jesuítas en el territorio de la nación. . (V. Documento $\mathrm{N}^{\circ}$ 1).

El periódico "La Sociedad" que con tanto acierto y valentia salió siempre a la palestra en defensa de los derechos de la Iglesia, comentaba así en su $\mathrm{N}^{\circ} 1112$, del 16 de Marzo de 1874, la tan cacareada vista fiscal de Paz Soldán: "La Carta Fundamental en el art. 23 establece: Puede ejercerse 
libremente todo oficio y profesión que no se oponga a la moral ni a la seguridad pública. En el art. 24 sanciona: La Nación garantiza la existencic y difusión de la instrucción primaria gratuita y el fomento de los establecimientos públicos de ciencic, artes, piedad $Y$ beneficencia. En el art. 25 decreta: Todos (aquí no se exceptúa a los jesuítas) los que ofrezcan las garantías de capacidad y moralidad prescritas por la ley pueden ejercer libremente la enseñanza y dirigir establecimientos de educación, bajo la inspección de la autoridad. En el ari. 23 la misma ley constitucional determina: Todo extranjero (sin excepción de nadie) podrá adquirir conforme a las leyes, propiedad territorial en la República, quedando en todo lo concemiente a dicha propiedad sujeto a las obligaciones $y$ en el goce de los derechos de peruano. $Y$, por fin, en el ari. 29 sanciona el deiecho de asociarse pacíficamente, sea en público o en privado, sin comprometer el orden público. Y más abajo proseguía: "Nuestros hombres públicos se hacen ridículos con citar leyes que han caducado y no tienen ya razón de ser. Esa córcel o inquisición política de la Mcnarquía española, obra del jansenismo ministe. rial, fué tiempo ha reducida a ruincs; sus grillos y cadenas pulverizados como cal y sobre ellos se ha levantando y se oxtenta imperante el majestuoso edificio de la Constitución Política de la República Peruana con todos sus adornos: los derechos, liberiades legítimas y garantías individucies y zociales que en ellas están sancionados. Y la ley injusta de 1853, a la que el señor Fiscal hace decir lo que no dice, fuera de ser nula, por ser oplesta al derecho de gentes $y$ a los principios constifucionales de la República $y$ de Ia Carta Fundamental entonces vigente, fué y está derogada, lo mismo que la ley española, por los artículos de la Constitución de 1360, actualmente en vigor, que hemos copiado. No: no hay con valor ley orgánica alguna que coniradiga $y$ anule las leyes posteriores que conceden absolutamente $y$ sin distinción ni restricción a todos, lo que aquellas negaban con insidiosa e injusta parcialidad. "Las leyes protejen y obligan igualmente a todos: podrám establecerse leyes especiales, porque lo requiere la naturaleza de los objetos, pero no por sola la diferencia de personas". (Constitución. Art, 32). (V. Documento No 3).

El Gobierno, presidido entonces por D. Manuel Pardo, vaciló un poco antes de tomar una resolución, pues sólo el 23 de Julio se expidió un decreto, ordenando al Prefecio de Huánuco intimase a los jesuítas la desccuodción del local de la Merced y, lo que era más grave, el que pudieran hacer vida de comunidad en cualquier otro lugar, apoyándose en las caducas leyes de Recopilación y en la ley anticonstitucional de 1855. (V. Documento $N^{\circ}$ 4). El decreto les fué dado a conocer el 16 de Setiembre $y$, sometiéndose al mismo, abandonaron el conventillo de la Merced y se refugiaron, primero, en algunas casas particulares $y$, finalmente, en el Palacio Arzobispal. Latía en medio de toda esta persecución la mala voluntad que siempre mostró el Presidente y su Gobierno al Obispo de Huánuco, Mons. Valle $y$, además, la inquina del Prefecto $\mathrm{y}$ de uno de los Senadores del Departamento contra los jesuítas. 


\section{VII}

\section{Ataque y Defensa}

La ley dada por la Convención el año 1855 prohibía llana y simplemente el restablecimiento de la Compañía de Jesús en el territorio nacional. El decreto de la Dirección de Culto en su parte dispositiva sólo ordenaba la desocupación del local de la Merced, la prohibición de que los titulados jesuítas hiciesen vida de comunidad y la entrega del conventillo al capellán nombrado por el Gobierno. Como sucede siempre que se evita tomar una actitud categórica y definida, los fundamentos en que se apoyaba el decreto eran deleznables. Se aparentaba desconocer que aquellos sacerdotes eran en efecło religiosos de la Compañía de Jesús. Mal podía ignorarlo D. Manuel Pardo, habiendo sido él, como Ministro de Relaciones Exteriores y Culto, el que autorizó al Obispo Valle a traerlos. Tampoco era cierto que su establecimiento en Huánuco se hubiese hecho sin licencia $y$, para ejercitar los ministerios propios de su cargo en la iglesia de la Merced, les bastaba la del Prelado. La casa habitada por los Padres y anexa al templo había sido adquirida por Mons. Valle, con el objeto de destinarla a los Ejercicios Espirituales del Clero y no podía considerarse tampoco como convento.

Era, además, improcedente citar las leyes de Recopilación y aun el Reglamento de Regulares de 1826, pues habían cc ducado, tanto por contrarias a la nueva Constitución como por haber caído en desuso. El único argumento que con alguna probabilidad se hubiera podido esgrimir era la ley de 1855, pero entonces no se debía haber hecho otra cosa que disolver la comunidad de Huánuco y prohibir su establecimiento allí y en Lima. No se hizo así y ante la protesta del Obispo, el Presidente Pardo ordenó que se devolviese al Prelado la casa anexa a la iglesia de la Merced y se permitiese a los Padres vivir en ella.

Entre tanto no falí quien saliese a la defensa de los perseguidos jesuítas. Cuando en Arequipa se tuvo noticia del atropello de Huánuco, el periódico "La Verdad", en un artículo publicado el 29 de Julio de 1873, ofreció en nombre de los católicos arequipeños un asilo en aquella ciudad a los hijos de Ignacio. En Lima intervino decidida y valientemente en su faror D. José Antonio de Lavalle y Pardo. Era senador por la Provincia y en la sesićn del miércoles 29 de Setiembre de 1874, presentó a la Cámara un proyecto de ley, derogando Ia de 1855 y autorizando a la Compañía a establecerse en el Perú y abrir Colegios, gozando de las garantías que ofrecía la Constitución. Se le dispensó del trómite de lectura y, habiendo consuitodo el Presidente señor Muñoz, si se le ponía en debate, la mayoría o sea 22 senadores votaron en contra. Sólo 16 votaron en favor y sus nombres merecen ser consignados: Gómez-Sánchez, García Pacheco, Olivera, Castilla, Araoz, Orihuela, Althaus, Secada, Salas, Forero, La Fuente, Villasís, Lama, Solar y La Torre (V. Documento $\mathrm{N}^{\circ} 5$ ).

En resumen, la intervención de Paz Soldón sirvió tan sólo para que de uno $y$ otra parte se esgrimiesen argumentos en pro o en contra de los jesuitas, pero ni el Gobierno se atrevió a expulsar a éstos ni se movió a colicar la malhadada ley de 1855. ¿Es qué había caducado en su concepto? Si nos 
atenemos a la letra del decreto dado por la Dirección de Culto en 1374 es preciso concluir que la consideraba vigente, pero no debía de estar muy firme en su juicio, cuando a renglón seguida añadía que, aun prescindiendo de dicha ley, la comunidad jesútica no podía subsistir por carecer del número que exigía el Reglamento de 1826: Este se hallaba ya en desuso $Y$ había sufrido diversas modificaciones: invocar un argumento tan débil $Y$ deleznable en reemplazo de otro más fuerte, denotaba que aun del primero no se hacía mucha cuenta.

\section{VIII}

\section{Se renueva el ataque en Lima}

En Lima, mientras tanto, se trataba con calor de fundar un Colegio. Abrióse al fin, el año 1878 y el Presidente, General D. Mariano Ignacio Prado, les hizo entrega de una parte del antiguo Colegio Máximo de San Pablo. La guerra vino a detener su florecimiento y muchos Padres abandonaron las aulas para acudir a los campamentos a prestar sus servicios como capellanes militares. Tanto en el ejército del Sur como en el destinado a la defensa de Lima, en los reductos de San Juan y Miraflores, se les vió asistiendo a los soldados y oficiales de la Reserva con abnegación y constancia. Nada de esto sirvió para que sus enemigos cesasen en sus ataques. Apenas abandonó el territorio el invasor volvieron las logias a revolverse contra ellos $Y$ la prensa liberal les hizo coro. (V. Documento $N^{\circ}$ 6). Por desdicha, un penoso incidente, provocado por uno de los Padres del Colegio, vino a añadir leña al fuego de las pasiones antireligiosas y exacerbó a nuestros enemigos.

En 1886 y en un tomo de 219 páginas en $8^{\circ}$ menor publicó el P. Ricardo Cappa un "Compendio de Historia del Perú". El primero en combatirlo fué Ricardo Palma, desde las columnas de "El Nacional". He aquí uno de sus párrafos: "¿A qué plan obedece la Compañía de Jesús, lanzando con la firma del más espectable de sus adeptos en Lima tan insolente cartel de reto? ¿Qué se ha propuesto al provocar un escándalo? ¿Quiere batalla campal? ¿Tan fuerte se considera ya que fía del éxito? El Gobiemo y el Congreso y con ellos el país entero estamos seguros de que han recogido el guante. Tiempo es ya de saber si es o no letra muerta la ley que cierra las puertas del Perú a los hijos de Loyola". Ciertamente que el autor del Compendio no se había propuesto desafiar a la opinión público, pero de hecho la imprudente aparición de su libro vino a servir de piedra de escándalo para muchos, aun de los que miraban si no con afecto al menos con respeto a la Compañía.

El P. Cappa que tuvo más de apologista que de historiador sereno e imparcial, hería en su libro la susceptibilidad nacional, asentando proposiciones de dudosa comprobación $y$ juzgando de nuestras cosas con un criterio nada favorable. Se había, pues, dado un arma a los contrarios y de ella so aprovecharon hábilmente, distinguiéndose como siempre, "El Callao", pe. riódico de filiación masónica y al servicio de la secta y los protestantes. Comenzó a solicitar firmas para un memorial en que se pedía la inmediata expulsión de la Compañía, mas, por fortuna, los jesuítas hallaroń un enérgico 
defensor en el celoso cura de la Matriz, D. Agustín Cardona, el cual neutralizó en gran parte la amenaza, haciendo circular entre los buenos chalacos una contrapropuesta.

Pero Palma había dicho con razón que estaba dada la voz de alarma y así fué. Por lo pronto, el 26 de Julio de 1886, el Ministerio de Culto dió un decreto en el cual se decía no hallarse reconocida por las leyes la ca munidad religiosa establecida en San Pedro y de carecer, por tanto, de personalidad jurídica $y$ de los derechos inherentes a las Congregaciones autorizadas la Compañía de Jesús. (V. Documento $N^{\circ}$ 7). Pudo el Gobierno del General Cáceres pensar que con este decreto se calmaría la efervescencia antilesuítica pero la hostilidad no cesó. En el Teatro Politeama hubo dos asambleas en las cucles se vociferó contra la Compañía y las csonadas a la pueria del Colegio se renovaban con frecuencia.

\section{IX}

\section{La Ley del Congreso de 1986}

El 27 de Setiembre de 1883 los dirutados Ingunza, Lecca, Deza y Tovar presentaron una moción pidiencio la inmedicia expulsión de los Jesuítas. (V. Documento No 8). Dispensada de lodo trámite se la admitió a discusión ₹ el señor Inqunua tomó la palabra para defender el provecto. Por sólo un voto de mayoría se dispuso que pasara a comisión y el 25 de Octubre era curobado y suecrito por el Presidente del Senado, D. Francisco García Calderén y el de la Cámara de Diputados, D. Alejandro Arenas. El art. 1웅 devio así: "Conforme a la ley de 30 de Noviembre de 1855 está prohibido el restablecimiento de la Compoñía de Jesús, como comunidad, como cong.encación, como cuerpo docente y bojo cualquier otra forma". (V. Documen. to $\mathrm{F}^{\mathrm{P}}$ 9). Los católicos todos protestaron y el 10 de Octubre se celebraba und asamblea en $\varepsilon 1$ Teatro Politeama de Lima con este fin. Arequipa secundó con su habitual energía a la capital y de todas partes se elevaron memoriales pidiendo al Gobierno suspendiese los efectos de la ley. Merecen mención especial la valiente Pastoral de Mons. Juan Ambiosio Huerta, Obispo de Arequipa y las notas que en "La Opinión Nacional" publicaron D. Andrés Avelino Aramburú y el Dr. Luciono Benjamín Cisneros.

El primero daba comienzo a un crí́culo por estas palabras: "Basta. Triunfó el legicidio. Un grupo de sacerdotes extranjeros que vino y vivió entre nosotros al amparo de la franquicia legal, hace sus maletas para abar. donar este suelo inhospitalario". Unas líneas más abajo, añadia: "¿Y cómo se ha realizado la expulsión? ¡Oh verguenza! Se ha realizado en el conciliábulo secreto, forjándose el rayo hipócrita, sin que nadie conozca las opiniones, eludiéndose la responsabilidad de ellas y dispứándose todos el papel de sayones o Pilatos: no se ha tenido el valor del debate ni la franqueza del voto público. Todo pasó en silencio desde la vociferación acusadora hasta el cobarde levantamiento de manos". El segundo, en carta al primero, deploraba como padre de familia el cierre del Colegio donde se educaba su' hijo Y se expresaba así: "Ayúdeme usted, pues, a deplorar el procedimiento de los que en nombre de la libertad y de lo que llaman respeto a la ley, nos 
han creado esta triste y deplorable situación y dígame usted si no tengo motivo para estar dolorosamente impresionado, viendo a mi hijo fuera de los claustros donde se deslizaba tranquila su inocencia. ¿Ganará el país con la supresión del Colegio de la Inmaculada Concepción? ¿Seremos desde hoy más morales, más virtuosos, más patriotas, más respetados, más dignos? No lo sé; lo que sé es que la autoridad ha sido concedida a Gobiernos y Congresos para el bien de los pueblos y, cuando se la ejerce, olvidando ente ideal, gobiernos y pueblos están amenazados de caer en el abismo".

El General Cáceres no podía olvidar que los Jesuítas lo habían acogido en su Colegio, después del desastre de Miraflores, habían curado sus heridas, lo habían ocultado a las miradas de los chilenos y habían facilitado su fuga al interior, donde abriría la heroica campaña de la Breña. Negóse a poner el cúmplase a la ley y constitucionalmente ésta quedó sin vigor, por entonces.

\section{$\mathrm{X}$}

\section{La dispersión y sus incidentes}

Para calmar la furia anticlerical pareció necesario ordenar la clausura del Colegio y este hecha determinó la dispersión de los Padres que lo tenían a su cargo. Unos se embarcaron con rumbo a Europa, otros se dirigieron a Bolivia y unos pocos quedaron en Lima. No se dió orden de expulsión pero el Presidente aconsejó que por el momento se hiciera el menor ruido posible. Un nuevo incidente vino a frustrar en parte este intento. El Obispo de Arequipa deseó aprovechar la presencia de los Padres que pasaban a La Paz parai dar una misión en la ciudad y con este objeto $\alpha$ los tres que habían venido de Lima se juntaron otros tantos que vinieron del Altiplano. Se clausuraba el jubileo del Año Santo y la Catedral de Arequipa apenas podía contener a los fieles que acudían $\alpha$ escuchar $a$ los misioneros. El día 6 de Enero de 1887 se dió término a esta fructuosísima campaña de saneamiento moral, con una pública profesión de fe de todas las clases sociales. La rabia mal contenida de los enemigos de los jesuítas vió en tales actos una amenaza. El Gobierno juzgó que peligraba su ascendiente en Arequipa y el Ministro del Solar ordenó al Prefecto, Manuel San Román, hiciese salir a los Padres y, previendo alguna resistencia por parte del pueblo, se envió al batallón Huamachucc. Intimada la orden, no opusieron los Padres dificultad alguna pues ellos estaban allí sólo de paso y los venidos de La Paz habían vuelto ya a este lugar. El Obispo, sin embargo, la Unión Católica de Caballeros y de Señoras y hasta particulares enviaron telegramas al Presidente para que revocase la orden e interesaran al Delegado Apostólico con igual motivo. Los telegramas quedaron $\sin$ respuesta y en cambio se recibió el siguiente del Ministro de Justicia: "Gobiemo extraña conducta jesuítas, cuya introducción durante receso Congreso es inconveniente. Gobierno con sus observaciones $\alpha$ ley ha dado una prueba de sus sentimientos y desea conservar su libertad de acción para momento oportuno. Introducción forzada de Padres y desobediencia a órdenes supremas alientan conspiraciones y comprometen orden público y resultado definitivo de la cuestión. Esperamos medite y aconseje sometimiento tranquilo como mejor medio de asegurar buenos resultados. Zegarra". 
Por las palabras de la comunicación telegráfica que hemos trascrito, podría creerse que los Padres intentaron quedarse en Arequipa, pero tal determinación no se les puede atribuir en manera alguna. Si no salieron antes, ello se debió a las instancias del Obispo y de gran número de personas que se lo suplicaron. Hubo, a nuestro juicio, un exceso de celo que las circunstancias desaconsejaban y dieron lugar a los bochornosos incidentes que se siguieron.

En la noche del 19 de Enero un pelotón de soldados allanó la casa del Obispo, penetró en las habitaciones interiores $y$ en un momento de in. sania llegó hasta poner las manos en el Prelado que se opuso a su paso y en los Padres a quienes se sacó violentamente del Palacio para conducirlos a la estación. Un oficial, el secretario de la Prefectura y un piquete de tropa los fué custodiando hasta la salida del tren. Se verificaron algunos arrestos entre las personas que habían acudido a la casa episcopal y sólo 20 días después se les dejó en libertad.

\section{XI}

\section{Amaina la tempestad.}

Los jesuítas clejaron que abonanzase el tiempo y dos años después de estos sucesos, abrían de nuevo, en. Abril de 1888, el Colegio de la Inmaculada de Lima. Después de este período de borrasca que duró, puede decirse, desde su crribo al Perú en 1871, se sucedió una era de paz que les permitió desenvolver su pacífica labor enire nosotros. Una vez admitidos, no se les expulsó, antes bien todos los Gobiemos, a partir del de D. Monuel Pardo, les dispensaron su protección $y$ hasta cierto punto les defendieron de los ataques y asechanzas del liberalismo radical y de la masonería. El Ejecutivo. menos expuesto a extrañas y malévolas influencias, debió siempre considerar que no exc posible, dentro de la Constitución, oponerse al establecimiento de un Instituto religioso como la Compañía de Jesús que no se proponía otra cosa sino hacer el bien y cuyos individuos obraban en entera conformidad con las leyes y costumbres del país.

La ley dictada por la Convención el año 1855 había caído por su base, desde la promulgación de la Constitución del 60. Esta en su art. 23 expresamente declaraba que "puede ejercerse libremente todo oficio, industria o profesión que no se oponga a la moral, a la salud ni a la seguridad públicas". No se establecía excepción alguna $y$, por lo tanto, los institutos religiosos aprobados por la Iglesia y cuycs constituciones en nada se oponían a la moral, a la salud, o a la seguridad públicas, tenían pleno derecho a est $\alpha$ blecerse en el país. A mayor abundamiento la misma Constitución en su art. 29 proclamaba el derecho de asociarse sin restricciones. "Todos los ciudadanos, dice, tienen el derecho de asociarse pacíficamente, sea en público o en privado, sin comprometer el orden público". Aun podría citarse el art. 25 en el cual se establecía la libertad de enseñanza y se autorizaba a ejecutarla, bajo la inspección de la autoridad a todos cuantos diesen garantías de capacidad y moralidad. ¿Por qué se había de hacer una excepción con los Jesuítas, cuando el art. 32 de la misma Constitución declaraba 
que la ley protegía por igual a todas las personas y vedaba el hacer distinción entre ellas? Con razón, pues, un jurista, como José Salvador Ca. vero, pudo concluir que la ley de 1855 "estaba en pugna con los principios fundamentales de derecho público, solemnemente proclamados cinco años después, al otorgarse la carta poltíica en vigencia".

Bastaba aplicar, por otra parte, el principio jurídico reconocido por nuestro Código Civil, a saber que cuando existe incompatibilidad entre una disposición constitucional y una legal, se ha de preferir la primera. Por lo mismo no se comprende como Paz Soldán hubiera podido insistir en la ley dada por la Convención y menos todavía que invocase la pragmática sam. ción de Carlos III, derogada, como hemos visto, por su sucesor Fernando VII. Después de él no se han aducido nuevos argumentos contra el de. recho de la Compañía de Jesús a establecerse en el Perú.

\section{XII}

\section{Respuesta a los legisladores del año 1886}

Innecesario parece volver a tratar de la ley del año 1886, puesto que ella fué vetada por el Ejecutivo y no alcanzó a producir sus efectos legales. Pero es conveniente saber que si el Gobierno de Cáceres se opuso a ella no lo hizo sin fundamento y éste lo expuso a las Cámaras un Ministro de entonces, jurisconsulto eminente y nada sospechoso de parcialidad con los jesuítas. En su Informe (V. Documento $N^{\circ}$ 10) decía así: "A juicio de Su Excelencia, el mencionado proyecto no está en completa armonía con las garantías individuales que nuestra Carta Fundamental consigna; con los principios fundamentales que presiden la organización de los pueblos libres ni, tal vez, con la opinión de la mayoría del país, opinión que es la regla suprema de gobierno en las naciones regidas por el sistema representativo.

"La libertad de las profesiones sin más reservas que las impuestas por la moral, la salud y la seguridad pública, el libre ejercicio de la enseñanza por todos los que comprueban la capacidad y moralidad prescritas por la ley $y$ el derecho de asociarse pacíficamente en público $y$ en priva. do, sin comprometer el orden público, están reconocidos por los artículos 23, 25, 27 de nuestra Carta Fundamental y estas valiosas garantías no son concesiones gratuitas del legislador sino el reconocimiento de derechos consugrados por la naturaleza del hombre y que los poderes públicos no pueden desconocer sin hacerse tiránicos".

\section{XIII}

\section{De nuevo interviene el Fiscal de la Nación}

Parece que después de lo dicho no era posible volver a la carga y repetir la añeja y maltrecha consigna antijesuítica, pero un buen día se le ocurrió al señor Seoane sacarla del olvido. Iban a celebrarse los solemnes funerales del difunto Arzobispo de Lima, Mons. Manuel Tovar, $y$ en el ceremonial adoptado figuraba entre las Ordenes Religiosas el nombre de la 
Compañía de Jesús. No era un secreto en Lima que esta Orden dirigía un Colegio, frecuentado por las mejores familias y, sin embargo, al Fiscal le llamó extraordinariamente la atención el que los jesuítas figuraran entre los demás miembros del clero, como si la sola inserción de su nombre les fuera a otorgar una especie de carta de ciudadanía. Se imaginó que tan inocente medida constituía una violación de la ley y pasó una nota al Ministro de Justicia reclamando del atentado. (V. Documento $\mathrm{N}^{\circ} 11$ ). No vale la pena repetir los considerandos del señor Seoane; sólo llamaremos la atención sobre dos puntos: reconoce el Fiscal que la ley dada por el Congreso de 1886 quedó en suspenso, a causa del veto del Ejecutivo y, por lo mismo, no hace fuerza en ella, pero al mismo tiempo cree que los jesuítas hasta entonces sólo han sido tolerados.

Esto último merece alguna refutación. No puede hablarse de tolerancia, en el caso de un estableciimento de instrucción que por su naturaleza tiene que estar abierto al público y en constante relación con las autorida. des, especialmente las encargadas del ramo de enseñanza. No se puede decir que eran tolerados, cuando en 1878 el Gobierno del General Prado les concede parte de un edificio de propiedad del Estado para que allí abran un Colegio; cuando, obedientes $\alpha$ un llamado de la autoridad militar y del Vicario General Castrense, reciben orden de incorporarse al Ejército Nacional en calidad de capellenes: cuando el Gobierno de D. Nicolás de Piérola, por un decreto, les confía el cuidado de la iglesia de San Peciro y los que le suceden en el mando, hasta el mismo D. José Pardo, autorizan con su presencia los actos públicos que se realizan en sus aulas. No se hizo pública la respuesta que el Ministro diera al señor Seocine, pero es seguro que debió abundar en conceptos algo parecidos a los ya expuestos y, por lo pronto, la intervención del Fiscal no tuvo otro resultado que el leve comentario callejero.

\section{XIV}

\section{Una nueva réplica}

Nos hallamos en el año 1910. La persecución que contra las Ordenes Religiosas se había desatado en Francia repercutió támbién en el Perú. Obedeciendo a una orden del Gran Oriente, la Masonería del Perú no quis. quedarse a la zaga de sus hermanos tres puntos de otras naciones y en la Cámara de Diputados los señores Pasquale, Urquieta y Chávez Bedoya, pidieron se adoptasen medidas a fin de evitar el ingreso de los sacerdotes extranjeros expulsados de Portugal y de Francia. No se olvidaron de los jesuítas y una vez más sacaron a relucir la ley de 1855 y su homóloga de 1886 instando al Gobierno porque se diese cumplimiento a entrambas. Ia respuesta vino a dársela el Ministro de Justicia, D. José Salvador Carvero, quien no hizo más que insistir en los argumentos expuestos antes por D. D. Luis Felipe Villarán. Al final de su razonada y serena exposición, decíales el Ministro arguyéndoles ad hominem: "Si los dogmas del credo liberal estriban en el respeto a la libertad de todos para que la propia sea respetada, me complazco en dar con esta ocasión un público testimonio del que 
profeso, reproduciendo en todas sus partes las observaciones antedichas, para declarar en conclusión que el Ejecutivo no se cree cutorizado para proceder contra los sacerdotes extranjeros en la forma propuesta por el señor Pasquale, a no ser que se establezca por el Congreso la ley prohibitiva 0 que ellos estén incursos en las restricciones que por razón de salubridad pública u otros motivos extraños a su carácter eclesiástico se expidan". (V. Documento No 12).

\section{$\mathrm{XV}$}

\section{Recopitulación}

Los jesútas al arribar a nuestras playas en 1871 y establecerse en el país estaban auiorizados a hacerlo por la Constitución entonces vigente. Nada se oponía a este acto legal que realizaban con conocimiento y aprobación de las autoridades y en vano podría citarse en contra, sea la orden de extrañamiento de Carlos III, sea la ley del año 1855. Esta por el mismo hecho de oponerse a la Cosntitución no podía considerarse en vigor. Las Constituciones cue después se han sucedido no sólo han ratificado los principios de la del 60 sino que los han ampliado y el Código Civil últimamente pra mulgado es una confirmación de esos principios. Después de esa fecha, su permanencia ininterrumpida entre nosotros, si no se vió libre de amenazas $y$ de intentos de proscripción, como la ley del año 1886, nunca se pudo considerar como ilegal, tanto porque dicha ley fué objetada constitucionalmente y no alcanzó a producir sus efectos, como por el tácito reconocimiento que de su posición jurídica hicieron todos los gobiernos que se han sucedido hasta hoy. Esta tácita aprobación ha venido a convertirse en pública u oficial todas las veces que a algún miembro de la Compañía de Jesús se le ha confiado alguna misión por parte del Estado o bien, como ha ocurrido recientemente, se ha encomendado a la Orden una empresa de todo punto nacionalista, como es la evangelización de los infieles de nuestro Oriente, al crearse la Prefectura Apostólica de San Javier del Marañón.

Pero por encima de todo esto hay razones de otro género que no es posible desàeñar. Una institución varias veces centenaria, extendida por todo el mundo y aprobada por la Iglesia se puede considerar como persona jurídica de derecho público y su personalidad no la recibe de un Estado cualquiera sino de la Iglesia misma que como sociedad perfecta e independiente del poder civil, puede constituir en su seno todas aquellas asociaciones que se juzguen útiles y provechosas para el fin a que ella misma está destinada.

Ahora bien, aunque las Ordenes Religioșas no puede decirse que formen parte de la jerarquía eclesióstica, como partes constitutivas de la misma, son, sin embargo, de derecho divino, como lo enseña Suórez y otros con él, pues el mismo Jesucristo es el institutor del estado religioso y son de derecho natural, por cuanto el fin de dicho estado es honesto, conforme a la naturaleza y tiende al perfeccionamiento del individuo. De ahí el que la Iglesia, una vez que ha aprobado las constituciones o estatutos de una Orden religiosa, la considera como cosa suya y la incorpora, por decirlo así, 
a su organismo. El Estado, en cambio, al reconocer a la Iglesia como sociedad perfecta $e$ independiente, no puede negarle el que le asiste de valerse de esas Ordenes $\mathrm{y}$, por lo tanto, ímplicitamente reconoce también su existencia. He ahí porqué en algunos de los Concordatos celebrados por la Santor Sede con los Estados Modernos, en el derecho de la Iglesia de promover sus fines por todos los medios que ella considera necesarios para alcanzarlos, se incluye el de lograrlo mediante el establecimiento y la propagación de los institutos religiosos.

Existiendo, por tanto, amigables relaciones entre la Iglesia y el Estado Peruano y reconociendo éste en la Constitución los derechos de aquella, constituiría una violación de estos derechos el que el Estado dejara de seconocer una Institución que la Iglesia reconoce, prohija y promueve y reconoce aliamente útil para sus fines.

Rubén Vargas Ugarte, S. J. 


\section{Documentos.}

\section{Ley de 23 de Noviembre de 1855}

\section{DOCUMENTO No 1}

La Convención Nacional del Perú decreta: Artículo Unico.-No es permitido el restablecimiento de la Compañía de Jesús en el territorio de la República. Comuníquese al Poder Ejecutivo para que disponga lo necesario a su cumplimiento mandándolo imprimir, publicar y circular. Dado en la Sala de Sesiones, en Lima, a 23 de Noviembre de 1855. Manuel Ezequiel Rey de Castro, Presidente. J. Simeón Tejada, Secretario. José Gálvez، Secretario. Al Presidente Provisorio de la República. Lima, Noviembre 30 de 1855. Cúmplase, comuniquese y publíquese. Rúbrica de S. E. Mar.

(V. El Peruano No 31, Tom. 29).

\section{DOCUMENTO No 2}

\section{Dictamen Fiscal sobre los Jesuitas de Huánuco.}

Excmo. Señor.-Desde 9 de Julio de 1873 el Prefecto de Huónuco avisó que el Rrdmo. Obispo Valie había dado posesión del templo de la Merced a los PP. Jesuitas y que se pretendía fabricar una casa para alojamiento de los mismos en la antigua sacristía, bajo el pretexto de casa de ejercicios para castigar en ella a los sacerdotes desmoralizados. En posteriores oficios de 12 de Setiembre de dicho año, de 10 y 31 de Enero del presente, ha repetido dicho Prefecto los mismos avisos, ratificando que parte de un terreno del Estado de que era enfiteuta la Sra. Lucar se había vendido a dichos jesuitas, con el fin de que se proporcionasen más espacio para el conventillo $\mathrm{y}$, asimismo que el Rev. Obispo le había hecho saber, por medio de su Secretario, la fábrica de la casa $y$, úftimamente, que por conducto del canónigo López se había solicitado que permitieran se trasladasen las referidos PP. a ese lugar, bajo el pretexta de que debiendo reunirse al Seminario, la casa del Sr. Obispo, no teníon los Padres Jesuitas otra habitación que el conventillo que de hecho se había establecido en Fiuánuco, habiéndose constituído en vida común, con iniracción de las leyes que prohiben en la República fundar conventos sin permiso de la autoridad nacional y de la ley de 23 de Noviembre de 1855, que ha declarado terminantemente que no es permitido el restable. cimiento de la Compañía de Jesús en el territorio de la República.

Es extraño que un asunto tan grave, en el que se hallan comprometidos y escandalosamente infringidas y desobedecidas los leyes de la República no hubiese llamado lá atención del Sr. Ministro del ramo en más de 7 meses corridos desde que recibió el primer aviso y que se haya mostrado impasible durante todo este tiempo hasta que se ha cercioracio de que el atentado cometido por el Rev. Obispo de Huónuco quedaba consumado; establecidos en comunidad los jesuitas, posesionados de propiedades del Estado y de supresos, cuya administración y aplicación corresponden al Gobierno, en virtud de cédulas reales, decretos y leyes de la República, por los que el Gobiema se subrogó en los derechos que gozaron los regulares de la extinguida Compañía de Jesús. 
Con el hecho ejecutado por el Rev. Obispo de Huánuco se han cometido infracciones de ley:

Frimera: la fundación de un convento para jesuitas contra lo expresamente dispuesto por la ley $1^{\alpha}$ tit. $3^{\circ}$, Lib. $1^{\circ}$ de la Recopilación de Indias que prohibe "se editiquen y funden conventos sin que antes se dé cuenta y pida licencia especialmente, como se ha acostumbrado en las Indias, con el parecer y licencia del Prelado diocesano, conforme al Concilio de Trento, y del Virrey, Audiencia del distrito o Gobernador e información de que concurren tan urgente necesidad y justas causas que verosímilmente pueden mover vuestro ánimo $y$ quedar informado, para lo que Nos fuéremos servido de proveer $y$ si de hecho o por disimulación se hicieren o comenzaren $\alpha$ hacer algunos de estos edificios, sin preceder la dicha calidad, los virreyes, audiencias o gobemadores los hagan demoler $y$ todo lo reduzcan al estado que antes tenían sin admitir excusa ni dilación y sea capítulo de residencia o visita para los dichos nuestros Ministros, si los consintiesen comenzar o comenzados lo disimulasen y no nos diesen cuenta en la primera ocasión".

Esta ley contiene la prohibición expresa de fundar conventos sin previa licencia del Gobierno y autoridades y también contiene la sanción penal por su infracción, reducida a mandar deshacer todo lo hecho.

La segunda infracción de ley es: el restablecimiento de la Compañía de Jesús, que no es permitida en el territorio dé la República, según la ley de 23 de Noviembre de 1855, mandada cumplir con fecha 30 de dicho mes y año.

Siendo constante el hecho $y$, estando mandado por la ley lo que debe hacer el Gobierno, se halla en Ia forzosa obligación de hacerla cumplir y por ello el Fiscal pide que.V. E. se sirva mandar se restablezcan las cosas al estado que tenían antes de que hubiesen sido llevados a Huánuco los jesuitas y fabricándoseles conventillo, como prescribe la ley de Indias, sin admitir excusa ni dilación, dóndose órdenes terminantes y eficaces al Prefecto del Departamento $y$, en caso de que no fuese obedecida por el Rev. Obispo de Huánuco la resolución de V. E. se pase todo a este Ministerio Fiscal, para interponer la correspondiente acusación a que hubiere lugar según derecho. Lima, Febrero 24 de 1874. Páz Soldán.

\section{DOCUMENTO No 3}

La Sociedad, en su No 1112 del 16 de Marzo de 1874, comentando la Vista Fiscal antecedente, indicaba valientemente, que toda medida gubernativa que no se inspirase y basase en la Carta Fundamental, no podía ser sino arbitraria y despótica y añadía:

"La Carta Fundamental en el art. 23 establece: "Puede ejercerse libremente todo oficio o profesión que no se oponga a la moral ni a la se. guridad pública". En el art. 24 sanciona: "La Nación garantiza la existencia y difusión de la instrucción primaria gratuita y el fomento de los ESTABLECIMIENTOS PUBLICOS de ciencias, artes, piedad $y$ beneficencia". En el art. 25 decreta: "TODOS (aquí no se exceptúa a los jesuitas) los que ofrezcan las garantías de capácidad y moralidad prescritas por la ley pueden ejercer libremente la enseñanza y dirigir establecimientos de educación, bajo la inspección de la autoridad. En el art. 28 la misma ley constitucional de- 
termina: "TODO (sin excepción de nadie) extranjero podrá adquirir conforme a las leyes, propiedad territorial en la República, quedando en todo lo concerniente a dicha propiedad, sujeto a las obligaciones $y$ "en el goce de los derechos de peruano". Y por fin, por el art. 29 sanciona el derecho de asociarse pacíficamente, sea en público o en privado, sin comprometer el orden público".

Pues bien: Qué crimen atentatorio ha cometido el Rdo. Obispo de Huánuco, apoyado en estos derechos y garantías constitucionales, con haber dado posesión del templo de la Merced a cuatro sacerdotes llamados, por la escasez del clero peruano, para profesores de su Seminario; fabricar una casa de ejercicios, establecimiento público de piedad garantido por la Constitución, en la antigua sacristía, para castigar en ella a los sacerdotes desmoralizados; comprar un terreno contiguo a ella, vendido en enfiteusis por el Estado, conforme a las leyes, a la señora Lucar, y traspasado en la forma legal, tomándolo por habitación de los profesores de su Seminario? Todo esto podía hacer libremente porque está concedido y garantido por los artículos de la Constitución del Estado, que acabamos de reproducir. El Rev. Obispo de Huánuco estaba en su derecho de dar el servicio del templo de la Merced a sacerdotes católicos que mantuviesen en él con decoro un culto que el Estado está obligado a proteger. En su derecho estaba de transformar su antigua sacristía en Casa de Ejercicios o en Establecimiento público de educación y ciencias y de colocar en ella a esos sacerdotes como a sus directores y profesores y de amplificar ese local con un terreno legalmente comprado.

„... Nuestros hombres públicos se hacen ridículos con citar leyes que han caducado y no tienen ya razón de ser. Esa cárcel o inquisición pclítica de la monarquía española, obra del jansenismo ministerial, fué tiempo ha reducida a ruinas; sus grillos y cadenas pulverizadas como cal, $y$, sobre ellas se ha levantado $y$ se ostenta imperante el majestuoso edificio de la Constitución política de la República Peruana con todos sus adornos; los derechos, libertades legítimas y garantías individuales $\mathrm{y}$ sociales que en ellas están sancionados. Y la ley injusta de 1855, a la que el Sr. Fiscal hace decir lo que no dice, fuera de ser nula por ser opuesta al derecho de gentes y a los principios constitucionales de la República $y$ de la carta fundamental entonces vigente, fué $y$ está derogada, lo mismo que la ley española, por los artículos de la Constitución de 1860, actualmente en vigor, que hemos copiado. NO; no hay con valor ley orgánica alguna que contradiga y anule las leyes posteriores que conceden, absolutamente y sin distinción ni restricción, a todos lo que aquéllas negaban con insidiosa e irjusta parcialidad. "Las leyes protegen $y$ obligan igualmente a todos: podrán establecerse leyes especiales, porque lo requiera la naturaleza de los objetos, pero no por sólo la diferencia de personas". (Const. art. 32).."

Luego pasa el articulista a preguntar por qué el Sr. Paz Soldán guarda silencio por lo que hace a las pagodas chinas, a los templos protestantes o a los masónicos, cuando en ellos se contraviene a lo establecido por la Constitución y las leyes o bien omite citar las disposicio- 
nes de las leyes españolas contra las sociedades secretas o los cuítos disidentes.

\section{DOCUMENTO $\mathrm{N}^{\circ} 4$}

\section{Resolución de la Dirección de Culto sobre la Casa de Huánuco.}

Lima, Julio 23 de 1874. Visto este expediente de que resulta que el M.R. Administrador Apostólico de Huánuco sin conocimiento de la autoridad pclítica mandó construir unas habitaciones en la antigua sacristía del templo de la Merced, servida por un capellán que nombra el Gobernador y solicitó enseguida del Prefecto del Departamento permiso verbal para establecer una Casa de Ejercicios con el fin de castigar en ella a los Sacerdotes desmoralizados, lo que fué negado por ei Prefecto, indicándole que ocurriese al Gobierno a pedir la licencia respectiva, que después exigió del Prefecto también verbalmente, que permitiese ocupar las habitaciones por los Sacerdotes Profesores del Seminario, que se titulan Jesuitas, Jo que fué negado, dando cuenta al Gobiemo; que aprovechando de la ausencia temporal del Prefecto se han constituído en ese conventillo y establecido en vida común los referidos sacerdotes y un lego, permitiendo apenas al capellán desempeñar las funciones de su cargo, y considerando quue por las leyes del Estado no es permitido fundar ni erigir iglesias, monasterios $u$ ciros lugares píos y religiosos, sin licencia expresa del Gobiemo y los edificios que con tal objeto se construyesen de hecho o por simulación, sin la referidá licencia, deben de ser demolidos, según lo disponen las leyes $1^{\alpha}$ Tit. $3^{\circ}$ y $2^{\alpha}$ Tit. $6^{\circ}$ del Lib. $1^{\circ}$ de la Recopilación de Indias. Que para $\epsilon$ l establecimiento del conventillo constituído en la que fué sacristía del supreso de la Merced de Fuánuco no se ha pedido licencia al Gobierno y se ha procedido con simulación: Que titulándose Jesuitas los que se han congregado en ese lugar para observar vida común no pueden ser tolerados por el Gobierno sin infringir las disposiciones legales que prohiben el establecimiento de esa institución en el territorio de la República y muy especialmente la ley de 30 de Noviembre de 1855; Que aun prescindiendo de estas resoluciones viqentes no podría subsistir la comunidad establecida en el expresado conventillo por no contener el número de conqregádos que requiere el Reglamento de 28 de Setiembre de 1826. Se resuelve: De conformidad con el dictamen del Fiscal de la Corte Suprema (') que el Prefecto de Huánuco tan luego como se panga en su conocimiento esta resolución, haga desocupar a los Jesuitas el local en que se han congregado e impida que se establezcan en comunidad en cualquier otro lugar, señalándoles un plazo perentorio para que salgán del Departamento en caso de resistencia o de contrariar sus órdenes, dando cuenta: Que el referido local, como todo lo anexo al supreso de la Merced esté, como antes, sujeto al cuidado y vigilancia del capellán y que se trascriba esta resolución al M. R. Adminisircador Apostólico de Huánuco, extrañando la conducta que ha observado con olvido de las leyes de la República.- Regístrese.- Comuníquese.- Publíquese.- Rúbrica de S. E.Sánchez.

\section{DOCUMENTO No 5}

La Sociedad, No 1264. Lima, 30 de Setiembre de 1874. Cámara de Senadores, Sesión del miércoles 29 de Setiembre de 1874. 
Presidencia del Sr. Muñoz.-A Abierta la sesión se leyó y aprobó la última acta. Se dió cuenta... - 7 . De la siguiente proposición:

El Congreso \&.- Considerando:

$1^{\circ}$ que la ley dictada por la Convención Nacional en 30 de Noviembre de 1855 así como cualesquiera otras disposiciones que existieran en la legislación colonial o patria, expulsando a los miembros de la Compañía de Jesús del territorio nacional o prohibiendo su ingreso o establecimiento en él, ya sea como individuos aislados, ya como corporación religiosa y docente, son contradictorios con lo que dispone la Constitución de la República en sus arts. $4 \%, 25$ y 29 , con el espíritu general de nuestras instituciones y con los principios de justicia universal.

$2^{\circ}$ Que nada hay en las constituciones de la Compañía de Jesús ni en sus actos que justifique la prescripción que sobre ella pesa.

$3^{\circ}$ Que antes bien, su establecimiento en la República pudiera ser altamente útil y beneficioso al desarrollo y propagación de la instrucción pública, como lo manifiesta la experiencia en otros países democráticos, como los EE. UU. de Norte América, Chile, la Gran Bretaña y Bélgica, en los que la Compañía de Jesús existe y florece sin inconveniente ninguno para el sistema político de esos países y con grande y eficaz provecho para la religión y enseñanza.

Da la ley siguiente:

Art. $1^{\circ}$ Derógase la citada ley de 30 de Noviembre de 1855 y todas las disposiciones que pudieran ser obstáculo al establecimiento en el territorio de la República de la sociedad religiosa conocida con el nombre de Compañía de Jesús y de sus miembros, ya sea como individuos aislados, ya como corporación religiosa y docente.

Art. $2^{\text {o }}$ Los miembros de la Compañía de Jesús pueden ingresar libremente en el territorio de la República, establecerse y residir en él, vivir separados y reunidos y abrir escuelas y colegios bajo las garantías que la Constitución ofrece en sus arts. 18, 20,25, 26, 27, 28 y 31 y gozando de los derechos y cumpliendo los deberes que las leyes secundarias y los tratados internacionales conceden 0 imponen $a$ los ciudadanos $o$ súbditos extranjeros en ella residentes, en su casa y respectivamente sin que por el hecho de ser miembros de dicha Compañía pueda sujetórseles ni como individuos ni como corporación a ninguna especial legislación.

Comuníquese \&.

Lima, Setiembre 29 de 1874. José Antonio de Lavalle.

Dispensado del trámite de lectura, S. E. consultó si se admitía a debate. Verificada la votación nominalmente, a petición de varios señores la proposición no fué admitida a debate por 22 votos contra 16, según consta de la siguiente lista:

Por el sí, los SS. Gómez Sónchez, García Pacheco, Olivera, Castilla, Lavalle, Araoz, Orihuela, Althaus, Secada, Salas, Forero, La Fuente, Villasis, Lama, Solar, La Torre. Por el no los SS. Rodríguez, Cisneros, Alegre, Lunc, Castillo, Montoya, Santisteban y Velarde, Torres, Acuña, Salazar, W. M. Aranívar, Camino, Montero, Oviedo, Agramonte García y García, Alvarez Calderón, Seminario, Goiburu y Vélez. 


\section{Acuerdo del Taller masónico de Lima.}

\section{DOCUMENTO Nং 6}

El her.: que suscribe, representante y garante de amistad de la Log.: No 57. "orden de Barcin", tiene el honor de presentar ante este Resp.: Tall.: la proposición siguiente:

Considerando

19.: Que, siendo uno de los fines de la mas.: trabajar por-difundir la verdadera luz en toda la humanidad; y al mismo tiempo que el bienestar de toda ella; que esto no se puede conseguir sin combatir toda sociedad. ya púbiica: ya privada, que tienda a comprimir la libertad del género humano y $q$. valiéndose de todo medio trate también de sumirlo en el oscurantismo.

$2^{\circ} .:$ Que, no habiendo en el Globo otra sociedad, q. sea más perniciosa para la humanidad, q. la "Sociedad de Jesús", como lo prueba la historia.

39.: Que, menospreciando las leyes y decretos vigentes del año de mil setecientos sesenti $Y$-siete por los cuales los jesuitas fueron expulsados de España y demás dominios; $y$ q. después fué confirmada esa expulsión por leyes y decretos, que no han sido derogados, dados por el Gobiemo republicano del Perú; se están introduciendo en el país, poco a poco, como sucede hoy en la ciudad de Huónuco.

4?.: Que así tan pocos como son ahora, ya sienten los vecinos de Huánuco, los malos efectos $q$. producen la estada de esos pocos de esa sociedad de ese punto; pues diariamente van infiltrando sus venenosas máximas: en las familias, apoderándose de las conciencias de las señoras, como las más fáciles de alucinarse con sus doctrinas religiosas y las disolventes máximas de su especiosa doctrina; moral y máximas $q$. no tienden sino a la ruina física y moral de las familias $y$ al enriquecimiento de esa perniciosa sociedad.

5!.: Que su teñdencia y todos sus trabajos se encaminan no sólo a introducirse en todos los ramos de la administración del País, sino también a usurpar sus riquezas, dominando las conciencias.

6:. Que dicha institución por su naturaleza, es una valla para los progresos de la Mas.:, sociedad tan sublime y tan altamente benéfica a la humanidad.

Propone

Que el R.: J.: ante el cual se hace esta moción, invite a todas las Log.: del Perú y a todos los demás.: en general, para que trabajen de consuno y con todo el entusiasmo debido, para la expulsión de los Jesuitas, haciendo valer todas las leyes y decretos vigentes $q$. existen anteriores $y$ posteriores a la Emancipáación del Perú.

Valle. de Lima \&\&.

\section{DOCUMENTO N $\mathrm{N}^{\circ}$}

Oficio del Ministerio de Culto.

Lima, Julio 26 de 1886 . Teniendo en consideración que de los antecedentes que existen en este Ministerio no aparece resolución alguna por la que se haya autorizado el restablecimiento de la corporación religiosa 
Jlamada Compañia de Jesús; que de las investigaciones ordenadas, para esclarecer este punto, resulta que ni se ha solicitado ni obtenido el permiso oficial, que las autoridades civiles deben conceder para el establecimiento de conventos y comunidades religiosas, a tenor de las leyes vigentes relativas a la fundación de Conventos; que los Padres de la Compañía de Jesús que enseñan en el local de San Pedro, no forman ni han podido formar una Corporación religiosa, sin el permiso ya indicado y carecen por tanto de toda personalidad jurídica correspondiente a una orden religiosa reconocida; el Gobierno declara no reconocer en los Padres Jesuitas que se hallan establecidos en San Pedro, el card́cter de orden religiosa, ni con la personalidad, ni con los derechos de las establecidas en el país con los mencionados requisitos.

Comuníquese, regístrese y publíquese--Rúbrica de S. E.-Pazos.

\section{DOCUMENTO N 8}

\section{Proyecto de Ley}

Los diputados que suscriben (Ingunza, Lecca, Deza y Tovar) tienen el honor de presentar la siguiente proposición:

El Congreso etc.-Considerando:

10-Que no obstante la prohibición expresa que contiene la ley de 30 de Noviembre de 1855, para el establecimiento de los jesuitas en el territorio de la República, y haber sido éstos expulsados en varias ocasiones por los anteriores gobiernos constitucionales, se han vuelto a introducir y establecer en el Perú, aprovechando el estado de guerra en que se ha hallado el país y de la punible condescendencia y protección indebida que les prestó el go bierno de Iglesias;

2:-Que los mismos motivos que entonces existían, existen hoy para no tolerar la residencia de los jesuitas en la república;

Ha expedido la siguiente resolución:

Dígase al Poder Ejecutivo que en cumplimiento de la citada ley de 1855 , dicte en el día, las órdenes de inmediata expulsión de los jesuitas del territorio de la república.

Comuníquese, etc.-Lima, setiembre de 1886.

Piden dispensa de todo trámite y su inmediata y preferente discusón.

Después de fundado por el Sr. Ingunza, el anterior proyecto fué admitido a debate, por todos los votos menos el del señor Puirredón; pero por 44 votos contra 43 se acordó no dispensarla del trámite de comisión y pasó a la de constitución.

\section{Ley de 25 de Octubre de 1886.}

\section{DOCUMENTO N 9}

El Congreso de la República Peruana.-Considercando:

Que es potestativo del Congreso interpretar las leyes.

Ha dado la ley siguiente:

Artículo 1\%. Conforme a la ley de 30 de Noviembre de 1855, está prohibido el restablecimiento de la Compañía de Jesús, como comunidad, como congregación, como cuerpo docente $\mathrm{y}$ bajo cualquiera otra forma.

Artículo $2^{\circ}$. El Poder Ejecutivo dictará las medidas conducentes a las ejecución de esta ley. 
Comuníquese al Poder Ejecutivo para que disponga lo necesario a su cumplimiento.

Dado en la Sála de Sesiones del Congreso de Lima a 25 de Octubre de 1886. F. García Calderón, Presidente del Senado. Alejandro Arenas, Presidente del Congreso. Cesáreo Chacaltana, Secretario del Senado. Teodoro A. Gadea, Secretario de la Cámara de Diputados.

Al Excmo. Señor Presidente de la República. Lima, Nov. 3 de 1886.

\section{DOCUMENTO No 10}

Lima, noviembre 3 de 1886.

Señores Secretarios del Congreso.-S. E. el Presidente de la República, a quien di cuenta de la ley sancionada por el Congreso que interpretando la de 30 de Noviembre de 1855 declara prohibido el restablecimiento de la Compañía de Jesús, como Comunidad, como Congrega. ción, como Cuerpo Docente y bajo cualquier otra forma, me ha encargado devolverla a UU. SS. HH., como tengo el honor de verificarlo, con las observaciones que paso a formular.

A juicio de S. E. el mencionado proyecto no está en completa armonía con las garantías individuales que nuestra Carta Fundamental consig. na; con los principios fundamentales que presiden la organización de los pueblos libres, ni tal vez con la cpinión de la mayoría del país, opinión que es la regla suprema de gabierno en las naciones regidas por el sistema representativo.

La libertad de las profesiones sin más reservas que las impuestas por la moral, la salud y la seguridad pública, el libre ejercicio de enseñan$z a$, por todos los que comprueben la capacidad y moralidad prescritas por la ley y el derecho de asociarse pacíficamente en público y en privado sin comprometer el orden público, están reconocidos por los artículos 23,25 y 27 de nuestra Carta Fundamental, y estas valiosas garantías no son concesiones gratuitas del legislador, sino el reconocimiento de derechos consagrados por la naturaleza del hombre y que los poderes públicos no pueden desconocer sin hacerse tiránicos.

Es una verdad fundamental establecida por el derecho moderno y que ya no se discute, que el poder del Estado cuyo ejercicio se encomienda a la autoridad pública, tiene por objeto único y por límite preciso la conservación de los derechos y es por eso que ese poder no debe ejercitarse para limitar la libertad individual sino cuando ésta lastima el derecho ajeño.

Las creencias religiosas, las verdades científicas y las evoluciones del trabajo y la actividad individual en todas sus fases son, mientras no constituyen el crimen o atentado contra las máximas de moral universal, do la exclusiva competencia de cada hombre o de cada asociación particular e independiente de la acción del Poder Público que ni ha recibido la misión de conducir a las almas a su salvación eterna, ni es el depositario de las verdades científicas, ni el director de la actividad humana en sus otras ma. nifestaciones.

S. E. comprende que bajo el régimen de los gobiernos absolutos cuando el Estado absorbía al hombre, nada quedase a la iniciativa ni a la espontoneidad del individuo porque la voluntad ilimitada del Soberano era 
la regla suprema de la vida social y la política de los pueblos, pero es inexplicable que cuando el hombre ha reivindicado su dignidad $y$ sus derechos en luchas seculares contra el poder absoluto de los reyes, el legislador o el administrador intenten regular las conciencias, dirigir las inteligencias y encadenar en sus estrechas prescripciones el vuelo infinito de la actividad humana.

Impedir a un grupo de hombres, sacerdotes del catolicismo, religión reconocida por el Estado y que goza de su protección exclusiva, la existencia en común para practicar su culto $y$ predicar su fe $\mathrm{y}$ ejercer la enseñanza y la caridad, pues tal parece ser la amplitud del proyecio, es Señores Secretarios, a juicio del Gobierno, separarse de las verdades que dejo establecidas, aun de las prescripciones de nuestro Código fundamental que no es por cierto el más liberal del mundo.

Y tal prohibición lastima también el derecho de los padres para elegir instituto para sus hijos y la libertad religiosa de las familias en ordei a la práctica del culto.

No cree S. E. que puede afirmarse que los afiliados en la Orden de Jesús constituyen hoy grupos absorbentes y peligrosos para la seguridad. dèl Estado.

Tales peligros podían temerse cuando los reyes ponían su poder absoluto a disposición de los directores de su conciencia, pero dadas las condiciones de la actual organización social y folítica de los pueblos, esos peligros son ilusorios.

En todo caso, el Código Penal y las leyes que garantizan la seguridad y el orden público establecen los medios suficientes para la represión del delito o de la inmoralidad disociadora.

Es por lo menos dudoso que la opinión del país, sea favorable al proyecto de que ze trata. El sentimiento de la libertad en unos, el fervor religioso, exagerado o no, en los demós, han protestado contra el indicado proyecto y esas protestas se levantan con el calor y. la agitación que inspirca el sentimiento religioso, el más vehemente tal vez en determinadas condiciones sociales.

Y cuando el país necesita reposo para rēhacerse y convalecer, ¿es político y prudente excitar los ónimos y despertar la turbulencia y el desorden? Cree S. E. que el patriotismo ordena ese camino y dirigir todos los esfuerzos a la conservación del orden, condición indispensable del trabajo y del progreso.

Por mi parte, señores Secretarios, me he complacido altamente en encontrar en el ánimo de S. E. el Presidente, estas ideas elevadas de verdadera libertad que forma mi credo social y político, ideas que he procurado arraigar desde hace 20 años en el espíritu de la juventud que acudé a los claustros universitarios, y me es sensible verlas abandonadas en el momento en que deben hacerse prácticas en las instituciones, en las leyes $\mathfrak{v}$ en las costumbres.

Espera por lo mismo S. E. el Presidente, que la alta sabiduría de las Cámaras Legislativas, sus elevados sentimientos de verdadera libertad y sus nobles propásitos encaminados a la consolidación de la paz pública. 
la decidirán a reconsiderar la ley de que me ocupo, desechándola del todo - armonizándola mejor con nuestras prescripciones constitucionales.

Dios guarde a UU. SS. HH.-Al margen rúbrica de S. E.-(Firmado) L. F. Villarán.

\section{DOCUMENTO No 11}

Oficio del Fiscal D. Guillermo Seoane.

Excmo. señor:-La Ley de 30 de Noviembre de 1855 prohibe el restablecimiento en el Perú de la Compañía de Jesús.

Por tal causa los RR. PP. Jesuitas que en 1872 pretendieron establecerse en Huánuco, y los que iniciaron la realización de igual propósito en otras localidades, hubieron de salir del territorio de la república, por mandato del gobierno, dentro de plazos perentorios.

En el programa que para el concurso del clero en las recientes honras fúnebres del infortunado arzobispo, señor doctor Tovar, proyectó el deán y aprobó el coro metropolitano, figura explícitamente nombrada la Compañía de Jesús.

Acudiendo al llamamiento, asistieron a la ceremonia, en calidad de miembros de dicha asociación, en el orden designado a las comunidades religiosas, los profesores que actúan en un colegio de esta capital; abierto hace algunos años, sin que el presbítero peruano, hoy canónigo, que se hizo personero ante el consejo superior para solicitar la autorización de la enseñanza, diese la filiación religiosa de su cuerpo docente.

Sin embargo de generalizarse desde tiempo atrás el regreso paulatino de los jesuitas, es evidente que las últimas administraciones han tolerado con su prescindencia al hecho ya consumado de la reinstalación, en sus comienzos sigilosa, atendiendo a las razones, aunque ilegales, que surgieran, a la par de los principios más difundidos del liberalismo, la aceptación de aquellos sacerdotes por un no pequeño círculo șocial, y la prosperidad de su plantel de instrucción.

La publicidad del programa antes mencionado y la comparescencia ya desembozadamente de la Compañía proscrita en acto oficial, a la vista del supremo gobierno y de las corporaciones, ponen aún más de relieve la infracción de su afrontamiento ante la autoridad a quien incumbe exigir la observanciá de la ley.

El congreso de 1886 tuvo a bien declarar que, conforme a la citada ley de 1855, estaba prohibido el restablecimiento de la Compañía de Jesús, como comunidad, como congregación, como cuerpo docente y bajo cucíquiera otra forma.

Las observaciones que entonces formuló el gobierno, dejaron en suspenso ya tal declaración.

Continuó así el estado de cosas cual si no se la hubiera hecho; y, por lo tanto, vigente como antes, la ley oportunamente promulgada en 1855.

El desuso no es derogatoria: ésta sólo corresponde al congreso. Por respeto a la majestad de la ley, es indispensable que se regularice la situacićn.

El fiscal de turno en lo administrativo cumple su misión al reprodu. cir ahora las observaciones que verbalmente expuso al señor ministro de] culto, el día de las exequias en la catedral. 
V. E. resolverá si procede el inmediato extrañamiento; 0 , si a mérito de lo excepcional del caso, conviene dar cuenta al poder legislativo, a fin de que en su sabiduría inicie con la derogatoria de la ley de 1855, si lo juzgare oportuno, la serie de reformas que en pro de la legislación civil reclama el progreso de la república.

Lima, 28 de Junio de 1907.-Seoane.

\section{DOCUMENTO NO 12}

Oficio del Ministro de Justicia y Culto y Presidente del Consejo a la H. Cámara de Diputados acerca de la permanencia de los jesuitas en el Perú.

Ministerio de Justicia y Culto.-Lima, 19 de diciembre de 1910.

Señores Secretarios de la $\mathrm{H}$. Cámara de Diputados.

He recibido el estimable oficio de UU. SS. HH. de 6 del mes en curso, en qua a solicitud del $\mathrm{H}$. señor Pasquale, y con acuerdo de la $\mathrm{H}$. Cámara, se insinúa la conveniencia de que se dicten por el Ejecutivo las disposiciones que estime conducentes, a fin de impedir el ingreso de sacerdotes extranjeros en el tenitorio nacional, a propósito de la expulsión de las órdenes religiosas recientemente decretada en el Portugal.

En contestación al citado oficio, por el cual se reitera el de 11 de noviembre último dirigido al despacho de gobierno a petición del mismo $\mathrm{H}$. senor Pasquale, a que se adhirieron los HH. señores Urquieta y Chávez Bedoya, cúmpleme decir a UU. SS. HH. que cuando se expidió la ley de 25 de Octubre de 1886, interpretativa de la de 30 de Noviembre de 1855 declarando "prohibido el restablecimiento de la Compañía de Jesús, como comunidad, como congregación, como cuerpo docente y bajo cualquier forma", el Ejecutivo la devolvió al Congreso con las incontrovertibles observaciones de mi antecesor $\in 1$ doctor don Luis Felipe Villarán, que contiene el oficio cuỵa copia acompaño, fecha 3 de Noviembre de 1886.

Ciertamente que la citada ley del 55, que prohibió el establecimiento de la Compañía de Jesús en el Perú, inspirándose en prejuicios tradicionales de la épcca colonial, que todavía predominaban entonces, está en abierta pugna con los principios fundamentales de derecho público, solemnemente proclamados cinco años después, al otorgarse la carta política en vigencia, en la cual se consagran tales y tañtas garantías a la liberiad y a los demás derechos de la persona humana, que la proscripción de los sacerdotes extranjeros, sea expulsando a los que ya se establecieron en el país y rechazando a los que acudan a nuestras playas en demanda de nuestra proverbial hospitalidad, constituiría una flagrante violación de la carta.

Si a nadie puede separarse de la República sino por sentencia ejecutoriada; si puede ejercerse libremente todo oficio, industria o profesión que no se oponga a la moral, a la salud o a la següridad pública; si todos los que ofrezcan garantías de capacidad y moralidad, pueden ejercer libremente la enseñanza y dirigir los establecimientos de educación bajo la inspección de la autoridad; si todo extranjero puede adquirir propiedad territorial en la república; si las leyes protegen y obligan igualmente a todos, pudien- 
do esiabiecer leyes especiales porque lo requiere la naturaleza de los objetos, pero no por sólo la diferencia de las personas (artículos 20, 23, 25, 27 . 32. de la Constitución); si los extranjeros gozan en el Perú de todos los derechos concernientes a la seguridad de su persona y de sus bienes y a la libre administración de éstos (artículo $33 \mathrm{C}$. C.) resultarían contrarias a la ley las medidas que se insinúan en los oficios que contesto, $y$, además afectarían hondamente el sentimiento religioso de la sociedad, ya no tratónclose de las congregaciones cuyo establecimiento nunca se prohibió en el Perú, sino aún de la Compañía de Jesús que con beneplácito general ha fundado en lima hace no pocos años uno de los mejores planteles de instrucción.

Si los dogmas del credo liberal estriban en el respeto a la libertad de todos, para que la propia sea respetada, me complazco en dar con esta ocasión un público testimonio del que profeso, reproduciêndo en todas sus partes las observaciones antedichas, para declarar en conclusión, que el Ejecutivo no se cree autorizado para proceder contra los sacerdotes extranjeros en la forma propuestá por el H. señor Pasquale, a no ser que se establezca por el congreso la ley prohibitiva, a que ellos estén incursos en las restricciones que por razón de salubridad pública $u$ otros motivos extraños a su carácter eclesiástico. se expidan.

Dios guarde a UU. SS. HH.- (Firmado) J. S. Cavero. 